\title{
Det nye våbenkapløb i international politik
}

Af Carina Ann Meyn

2018 var et skelsættende begivenhedsrigt år i den internationale atomvåbenpolitik. I foråret udkom Trump-administrationens samlede atomvåbenstrategi, The Nuclear Posture Review, der fik skruet ned for optimismen og i stedet defineret Rusland og Kina som centrale strategiske udfordrere, man har til hensigt at væbne sig forudseende og teknologisk overlegent imod. Mere spektakulært fik Putin - stik mod de brede befolkningers normalopfattelse af våbenkapløb som et overstået kapitel i international politik - løftet sløret for en række nye og sofistikerede atomvåben, der alle har til formål at kunne omgå den nyeste missilskjoldsteknologi.

Traktatmæssigt blev det samtidig året, hvor USA trak sig ud af Iran-aftalen på trods af både sine ministres og efterretningstjenesters vurdering af sagen - og endelig året, hvor Trumpadministrationen valgte at udstikke et
60 dages ultimatum til Rusland om at vende tilbage til INF-traktaten, inden USA tager konsekvensen og forlader aftalen.

Alle disse nybrud påvirker dansk sikkerhedspolitik og det europæiske nærområdes geopolitiske grundvilkår, idet vi nu står over for et større våbenkapløb og en mulig remilitarisering af det europæiske kontinent. I årene forude vil det således være en central udfordring enten at bremse eller tilbagerulle de sikkerhedspolitiske logikker, der igennem årene har opløst tilliden og forståelsen mellem stormagterne.

I en praktisk, politisk og ideologisk henseende kan Europa med fordel i denne sammenhæng påtage sig en medierende og historieoptegnende rolle, der kan pege i en tredje retning fra USA's oprustningsivrige kurs og Ruslands lige så reaktive og revanchistiske sikkerhedspolitiske linje. En central udfordring bliver dog, at med opløsningen af INF-traktatens stabilitetsfremmende forbud mod landbaserede kort- og mel-

Carina Ann Meyn er adjunkt ved Institut for Strategi på Forsvarsakademiet med fokus på klassisk strategi og praksis-orienterede analyser af det atomvåbenpolitiske område i international politik. 
Efter årtier med eksistentiel usikkerhed og klare ideologiske skillelinjer i international politik blev USA efter Sovjetunionens sammenbrud udnævnt til den ubestridte vinder af den kolde krig og den eneste tilbageværende supermagt i den internationale orden.
Efter årtier med eksistentiel usikkerhed og klare ideologiske skillelinjer i international politik blev USA efter Sovjetunionens lemdistancemissiler, kan vi forvente at se en dybere splittelse komme til udtryk internt både i NATO og EU, hvad angår den opfattede trussel fra Rusland og de mest hensigtsmæssige modsvar hertil.

\section{Hvordan nåede det så vidt?}

Det hele virkede så fredeligt og godt indtil det lige pludselig ikke gjorde det længere.

Efter den kolde krigs ophør og optimismen, der fulgte, løftede bekymringerne sig i den brede kollektive bevidsthed for truende scenarier med stormagtskonflikt og hastige våbenkapløb. Den progressive og håbefulde præsident Obama udlagde for en entusiastisk menneskemængde i Prag i 2009 sin vision om at arbejde for en atomvåbenfri verden - og blev siden belønnet for sine principper og sikkerhedspolitiske udsyn af Nobels Fredskomité.

Kun ti år senere befinder vi os nu ved en tydelig skillevej i den internationale sikkerhedspolitik, der er kommet bag på de fleste og bekymrer statsledere ikke bare i Danmark, men over hele verden. Det vigtige analytiske spørgsmål at få klarlagt er derfor: hvordan nåede det så vidt? Hvilke fejl og misforståelser, som ikke i øjeblikket forekom graverende, blev der begået undervejs? Og hvorfor holdt vores forståelse af stormagtspolitikken stille - som frøen i en langsomt opvarmende gryde - til langt ud over rimelighedens grænser? sammenbrud udnævnt til den ubestridte vinder af den kolde krig og den eneste tilbageværende supermagt i den internationale orden. Dette affødte i mange år en ukuelig optimisme og fremtidstro, men havde samtidig også en væsentlig skyggeside i USA's nye selvopfattelse og politiske prioriteringer.

Som et naturligt led i en vinderdiskurs må man nemlig også have tabere, som - per retorisk trylleslag - ikke anses med den samme respekt, empatiske indlevelse eller akutte krigsfrygt som tidligere. I årene efter den kolde krigs ophør blev en række russiske protester om landets centrale sikkerhedsinteresser således fejet af bordet, idet de fremstod enten unødigt beklagende, alarmistiske eller slet og ret irrelevante grundet landets fald fra magtens tinder og den brede globale trusselsforståelse i øvrigt.

Her finder vi altså den første ingrediens i opskriften på det forværrede politiske forhold mellem USA og Rusland i dag: Den implicitte negligering af reciprocitetsdynamikkerne i international politik.

\section{Terrorangrebene $9 / 11$}

Ingen anden begivenhed i nyere politisk historie har betydet så meget for amerikansk udenrigs- og sikkerhedspolitik som angrebene den 11. september 2001. På et øjeblik ændredes USA's selvopfattelse fra at være 'den vindende supermagt' til - med tvillin- 
getårnenes kollaps og Pentagon-bygningen i kaos og flammer - 'den sårede supermagt'. Den umiddelbare reaktion førte som bekendt til årtiers militært engagement i Mellemøsten, men langt mindre omdiskuteret førte USA's nye sårbarhedsfølelse og dybe choktilstand også til landets udtræden af ABM-traktaten i 2002 og en hel række nye våbenteknologiske opprioriteringer $\mathrm{i}$ årene, der fulgte.

The Anti-Ballistic Missile Treaty også kaldt ABM-traktaten (1972) - blev oprindeligt indgået på baggrund af en fælles forståelse af de usikkerhedsskabende effekter, som opstillingen af strategiske forsvarssystemer ville medføre mellem stormagterne. Helt enkelt indså man i USA såvel som Sovjetunionen, at strategiske forsvarssystemer ville ændre markant på cost-benefit-analyserne i afskrækkelsespolitikken - og derfor potentielt føre til langt større incitamenter for afvæbnende præventive angreb, end man havde lyst til skulle være gældende som grundvilkår i det politisk anstrengte forhold mellem stormagterne.

Centralt i den fælles forståelse, som ABM-traktaten repræsenterede, lå således en anerkendelse mellem stormagterne af, at stabilitet afhang af stormagternes reelle forsvarsløshed mod uprovokerede overraskelsesangreb. Det kan lyde kontraintuitivt, men baggrunden er, at i en kontekst uden begrænsninger på strategiske forsvarssystemer
Man kan sammenligne situationen med en duel, der finder sted mellem to pistolbærende konfliktparter. Alt andet lige vil den person, der under skjorten har fået installeret en helt ny teknologi, nemlig beskyttelsesvesten, have en væsentlig strategisk fordel over den person, som går ind $i$ duellen uden en sådan opfindelse.

kunne et land, som havde opnået relativ fordel på sine defensive systemer, være drevet af en præventiv sikkerhedslogik mod et afvæbnende angreb på sin nærmeste konkurrent.

Man kan sammenligne situationen med en duel, der finder sted mellem to pistolbærende konfliktparter. Alt andet lige vil den person, der under skjorten har fået installeret en helt ny teknologi, nemlig beskyttelsesvesten, have en væsentlig strategisk fordel over den person, som går ind i duellen uden en sådan opfindelse. Missilskjold virker grundlæggende på samme måde. Selvom det er en defensiv teknologi, udgør det en strategisk 'gamechanger' på hele det sociale felt af internationale konkurrenter - og gør alle mere nervøse for, hvad der kan ske, når en stærk modstander føler sig tilnærmelsesvist usårlig.

Allerede inden Præsident Obamas optimistiske og samarbejdsorienterede nedrustningspolitik havde amerikanske magthavere med ABM-udtrædelsen i 2002 altså lagt grundkimen til en hastigt voksende mistillid mellem

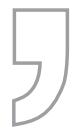

Samlet set var årtierne efter den kolde krigs afslutning ikke en fredens og forståelsens æra i international sikkerhedspolitik - selv hvis vi fraregner ekspeditionskrigene i Irak og Afghanistan - men derimod en ny usikkerhedsskabende tidsalder. 


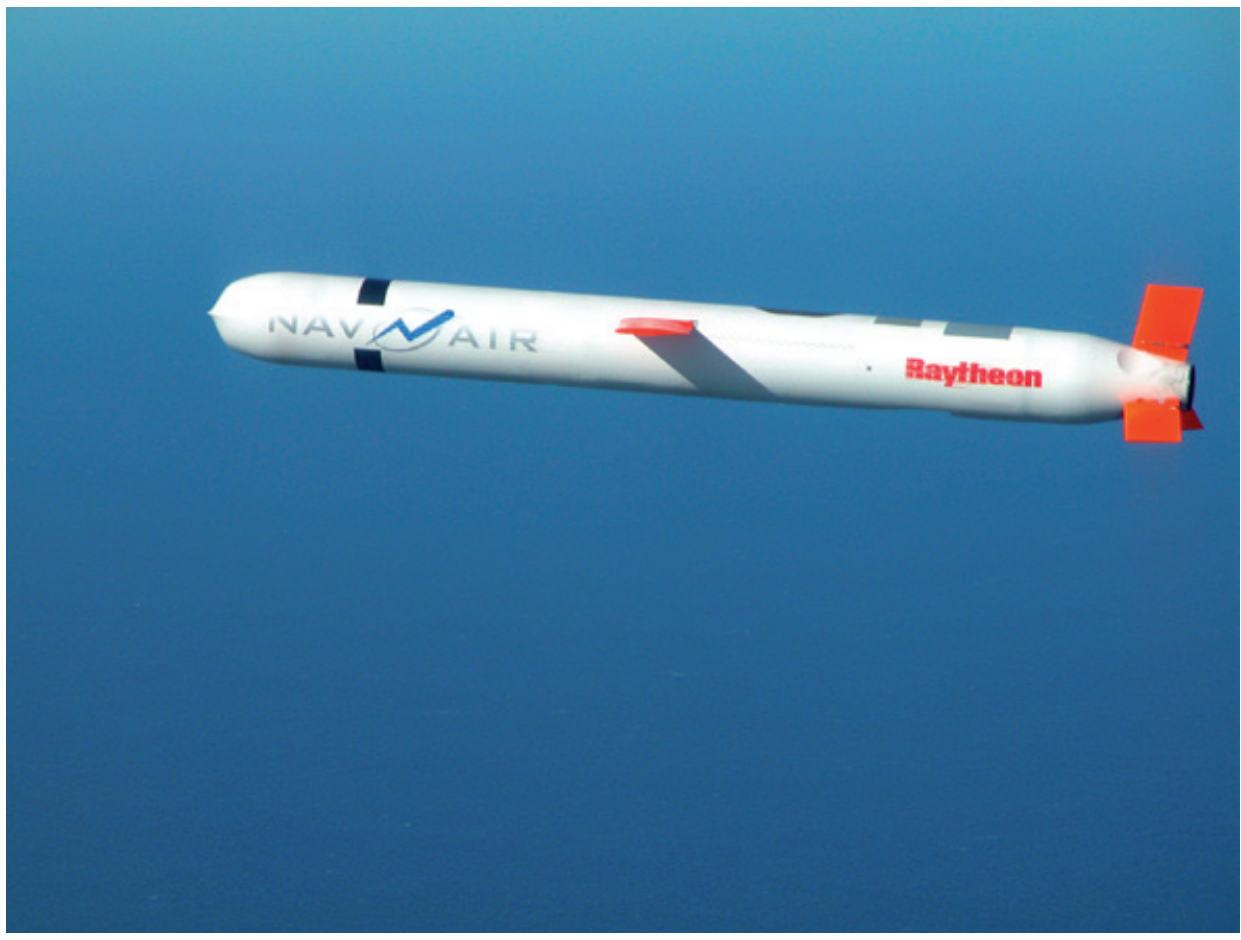

FOTO: US Navy

Taktisk 'Tomahawk' Block IV krydsermissil på testflyvning, oktober 2002

de gamle atombevæbnede stormagter $\mathrm{i}$ international politik. Over tid blev dette kun forværret - først og fremmest af USA's Mellemøstpolitik om 'regime change' via vestlig militærintervention og dernæst af Obamaadministrationens fortsættelse af Bush-regeringens missilskjoldspolitik, der førte til nye militærinstallationer i Polen og Rumænien.

Samlet set var årtierne efter den kolde krigs afslutning ikke en fredens og forståelsens æra i international sikkerhedspolitik - selv hvis vi fraregner ekspeditionskrigene i Irak og Afghanistan - men derimod en ny usikkerhedsskabende tidsalder, hvor veletablerede normer og regler ukritisk blev forladt til fordel for nye teknologiske landvindinger og individuelle sikkerhedshensyn.

Den anden hovedingrediens i det forværrede stormagtsforhold kan derfor siges at være: et normskred i den internationale strategiforståelse, der endnu ikke har ført til nyforhandlede grundopfattelser og færdselsregler, der løser op for nogle af de mest graverende usikkerheder i det nye sikkerhedsdilemma, vi ser udvikle sig i international politik.

\section{Komplekse våbenkapløb}

Traditionelt set har sikkerhedspolitiske analytikere været vant til at tænke strategi og sikkerhedsdilemmaer i 
Det, som vi ser udvikle sig i international politik i

disse år, er nemlig et nyt våbenkapløb, der mere er kvalitativt end det er kvantitativt. Et nyt våbenkapløb, som foregår på tværs flere forskellige våbenteknologier og fysisk/virtuelle domæner samtidigt. cyber, missile defense, global strike, electronic warfare, intelligence, targeting, and [so on]". Sagt på en anden måde er den grundlægenkle binære termer. Det vil sige: som en udfordring, der eksisterer mellem to supermagter og primært omhandler én masseødelæggende våbentype, nemlig atomvåbenet. Denne analytiske praksis udfordres i disse år af tilblivelsen af et langt mere komplekst våbenkapløb - ikke bare mellem USA og Rusland - men mellem de gamle stormagter og de opstigende mellemmagter på én og samme tid.

Dette gør det langt mere svært for strategiske analytikere og sikkerhedspolitiske forskere at advare i tide om nye sikkerhedsudfordringer i den samlede sikkerhedspolitiske balance, idet ligningen for sikkerhed og stabilitet er blevet langt mere kompleks end tidligere. Det, som vi ser udvikle sig i international politik i disse år, er nemlig et nyt våbenkapløb, der mere er kvalitativt end det er kvantitativt. Et nyt våbenkapløb, som foregår på tværs af flere forskellige våbenteknologier og fysisk/virtuelle domæner samtidigt.

Som chefen for The US Strategic Command, General Hyten, forklarer sin egen opgaveportefølje, består USA's strategiske forsvar ikke længere kun af atomvåben:

"When I say, 'we will provide a strategic deterrent [and] if deterrence fails, we'll provide a decisive response' [...] everybody [thinks of] nuclear capabilities, but it actually applies to every element of this command: nuclear, space, gende strategiske ligning i international politik ekspanderet til en række nye teknologiske områder, når stater forholder sig usikkert til hinanden og skal beslutte sig for en passende våben- og informations-teknologisk kurs. Dermed er det altså ikke uvæsentligt eller trivielt, når de konkurrerende parter i international politik udtrykker bekymring over udviklingen i eksempelvis konventionelle præcisionsvåben, missilskjoldsteknologi, offensive cyberkapabiliteter og antisatellitvåben - for, som General Hyten selv forklarer det - hænger disse kapaciteter sammen i det relative styrkeforhold, som udvikler sig mellem staterne i international politik.

Med kompleksitet som det nye grundvilkår i international sikkerhedspolitik og magtudlignende ambitioner på spil fra både Rusland og Kina i den nye sikkerhedspolitiske kontekst er der rigtig mange nye våbentyper, fremføringsmidler og systemkompromitterende teknologier under udvikling i international politik i disse år.

For det første investerer USA, Rusland og Kina alle med væsentlige beløb i deres gamle atomare infrastruktur. For det andet er alle de største spillere i international politik i færd med at udvikle hypersoniske våbensystemer for at genvinde en uberegnelig angrebsfordel over strategiske modstandere. Endeligt arbejder både store og små nationer sig ubemærket ind i konkurrerende nationers 


\section{Hvordan kommer alle disse udviklingstendenser til at påvirke Danmarks sikkerhed og den fælles europæiske udenrigs- og sikkerhedspolitik? Kort sagt vil den på ny gøre det europæiske kontinent til den reelle fortrop i en eventuel atomkrig mellem stormagterne - præcis som under de mørkeste dage af den kolde krig.}

kritiske infrastruktur, særligt sensitive systemer og teknologiafhængige situationsbilleder - i tilfælde af fremtidige kriser og konflikt, hvor åbninger som disse vil kunne påvirke kampeffektiviteten på afgørende vis.

Til generel skræk og advarsel har USA for eksempel kunnet angribe Nordkoreas missilprogrammer via cybervåben, hvilket naturligvis får andre atomvåbenmagter til at bekymre sig over den langsigtede integritet og effektivitet af deres egen strategiske slagstyrke.

\section{Gamle våbentraktaters kollaps}

Som en naturlig blindtarmskrise, der finder sted midt i en række nye våbenteknologiske kapløb, er INF-traktaten de senere år kommet under pres fra både russiske og amerikanske våbendispositioner. Senest har et samlet NATO fordømt Rusland for at opstille et nyt landbaseret krydsermissil, og USA truet med traktatexit i respons på den praktiske udvikling. Allerede inden disse udmeldinger påpegede russerne imidlertid det urimelige $i$, at USA opstillede missilskjoldsteknologi i Polen og Rumænien, idet Aegis Ashoreplatformene, som anvendes til dette formål, kan bruges både til affyring af antiballistiske missiler, men også til INF-overtrædende Tomahawk missiler.

De divergerende sikkerhedspolitiske vurderinger af sagen til trods har USA den 17. januar endeligt besluttet, at de ovenpå de mangeårige russiske brud på traktaten vil påbegynde en formel udtrædelsesproces den 2. februar 2019. Dermed vil en central sikkerhedsfremmende grundpille fra afslutningen af den kolde krig være fejet endeligt af vejen til fordel for ubegrænsede udviklingsprojekter og våbendeployeringer i fremtiden.

Blandt sikkerhedspolitiske analytikere forventer man, at INF-traktatens kollaps også vil betyde et endeligt ophør af den strategiske våbenkontrol mellem USA og Rusland, når New START-aftalen formelt udløber i februar 2021. Funktionelt set vil en lang æra med ordnet våbenkontrol derfor blive afløst af en ny periode med tiltagende våbenteknologisk konkurrence og usikkerhed.

\section{Fremtidsperspektivet}

Hvordan kommer alle disse udviklingstendenser til at påvirke Danmarks sikkerhed og den fælles europæiske udenrigs- og sikkerhedspolitik? Kort sagt vil den på ny gøre det europæiske kontinent til den reelle fortrop i en eventuel atomkrig mellem stormagterne - præcis som under de mørkeste dage af den kolde krig. Derfor så vi den franske præsident Emmanuel Macron tordne mod Trumps pludselige udmelding tilbage i oktober 2018. Den fælles NATO-fordømmelse af Ruslands traktatovertrædelser kan i 
denne sammenhæng kun ses som en modstridende PR-redning fra de europæiske allierede til den uregerlige storebror i NATO-samarbejdet, der gang på gang underminerer sine nærmeste allieredes tillid og respekt.

De nye sikkerhedspolitiske afvejninger, der vil finde sted oven på disse udviklingsforløb, ser vi allerede nu pible frem i international politik. I den europæiske kontekst har Macron fremlagt en ambitiøs vision for et styrket fælleseuropæisk sikkerhedssamarbejde, idet vurderingen går på, at Europa ikke længere kan stole på andre til at garantere sin sikkerhed og stabilitet. Angela Merkel og mange andre har støttet op om disse betragtninger - og nye realpolitiske sikkerhedsberegninger finder derfor allerede sted ikke bare i Europa, men også i Asien, hvor USA's allianceforplig- telser og militære engagement er blevet forsøgt annulleret og trukket tilbage af præsident Trump op til flere gange dog foreløbig uden held, takket være den tidligere forsvarsminister James Mattis og en række andre centrale medarbejdere i Det Hvide Hus.

Samlet set står vi over for en helt ny æra i international politik, hvor vi både skal lære at tænke og handle på en anden måde end tidligere. Som europæere bliver vi i denne sammenhæng nødt til at mobilisere vores historiske bevidsthed, fælles kerneværdier og progressive visioner - for på nogen måde, med argumentet og eksemplets magt, at kunne trække i den modsatte retning af oprustningslogikken, den modsatte retning af normbruddet, den modsatte retning af konflikt. 